\title{
Key educational concepts and students' worldview development elaborated by K.D. Ushinsky
}

\author{
E. V. Moskaliuk \\ Odessa National Maritime University \\ Corresponding author. E-mail: moskalyukev@gmail.com \\ Paper received 27.04.18; Accepted for publication 01.05.18.
}

\section{http://doi.org/10.31174/SEND-PP2018-165VI69-05}

\begin{abstract}
The article deals with the idea of educational system development of K.D. Ushinsky. This system is actualized with leading educational questions, the updating of the education content, educational methods and technologies. Pedagogical ideas of K.D. Ushinsky about comprehensive development of the student`s personality, the features of the relationship of the teacher and students within the learning process can be demanded by the modern school in their synergy with the concepts of individualization of learning, studentcentered learning, competence-based approach. It should be noted that K.D. Ushinsky is our national teacher, his ideas are relevant nowadays. Furthermore, the pedagogical concepts of K.D. Ushinsky and their importance for modern education, developing under the influence of the processes of globalization and integration have been analyzed. It should also be emphasized that Ushinsky was not only a great expert in teaching, but also paid considerable attention to questions of education.
\end{abstract}

Keywords: personality, world-view, individualization of training, student-centered learning, competence approach.

Formulation of the problem. In modern countries of European Union pedagogy begins to dominate the approach to education is not as purposeful formation of personality in accordance with the chosen ideal, and how to create conditions for self-development of personality. A successful educational activity of students depends not only on the degree of knowledge of intellectual activity methods; it is also due to the personal settings of educational activity, stable system of relations of the student to the world and to itself.

Besides the development of the modern community is carried out against the background of a crisis in the social, economic, political spheres and, as a consequence, in the sphere of education. An unceasing search for new, more advanced approaches to learning is becoming more urgent. Today there is no doubt that a modern and competent person is not someone who has a ready set of knowledge, but one who is able to navigate the incoming information flow, selecting the valuable and necessary, while supplementing and improving the personal knowledge system. In this regard, not only the supplying of students with certain information, but also the development of the ability to comprehend and formulate their own judgments on this basis should consider the main purpose of the educational process. Thus, the priority of modern education is the development of the ability to transform "theoretical and practical knowledge into problem-solving strategies and methods of obtaining new knowledge, into one's own know-how" [2, p. 371].

It should be noted that the issue of the upbringing of a harmonious self-thinking personality in the learning process has already been raised in the writings of the past outstanding scientists, among which a prominent thinker and educator. Ushinsky Konstantin Dmitrievich is a famous teacher. He graduated from the faculty of law of the University of Moscow and moved to St. Petersburg. Here he contributed to the Sovremennik and Biblioteka dlya Chteniya journals. In 1854 , he took on a teaching job at the Gatchina Orphan Institute, where he performed the functions of supervisor. He was the supervisor of Smolny Institute, where he implemented progressive reforms. Also he edited the Zhurnal Ministerstva Narodnogo Prosvescheniya journal. From 1862 to 1867 , he lived abroad and studied foreign teaching techniques. A founder of domestic science of education, Ushinsky left classical textbooks entitled The Children's World and The Mother-Tongue [6]. He spent five years in Switzerland and Germany and gained a remarkable knowledge of problems concerning European education. The pedagogical theory of Ushinsky is based on the idea of the national character of education, which aims at the development of an active and creative personality. The educator believed that education should devote itself primarily to the formation of character. According to Ushinsky, "life without serious work can be neither worthy nor happy". Ushinsky underlined the personal influence of the teacher as an educational force. He was interested in foreign educational systems [6].

It is thus understandable that the prestige of Ushinsky is bound to increase at the international level as the relevance of his work to contemporary problems. In fact, some ostensibly new fields of education were anticipated by him more than a century ago. At that time comparative education was hardly spoken of, but in fact Ushinsky was already intensely interested in it as can be seen in his comparison of Western European education with the situation prevailing in Russia. Furthermore, the theory of adult education as a special educational discipline had not yet been accepted. Ushinsky, however, contributed to it by his profound meditation on Sunday schools. The problem of mass education and literacy in developing countries was not a prominent one because those countries were still colonies. Russia itself was then in some respects a developing country. Ushinsky was aware of this fact and concerned himself, more than a hundred years ago, with this problem, namely to what extent foreign educational models should or should not be adopted and what role should be assigned to national traditions. In those days there was still considerable prejudice against women's access to education, but Ushinsky believed that women ought to receive the same education as men and that both sexes had an equal right to obtain higher education at university.

In addition, if we were to express extremely briefly the essence of Ushinsky's education, we could do so by using the following four words: nationality, language, work, science. We could develop these as follows: nationality in the world context; language as a tool of knowledge; science as 
a basis of art; work as a source of happiness. He did not deny the importance of objective teaching and active work by the student. He was, however, aware of the major role of language in the development of thinking and learning and, for this reason, he saw in language teaching an important tool for learning facts. His method is generally referred to as obiyasnitelnoye cteniye (reading with explanation) and was one of the main methods not only of language teaching. Reading with explanation is naturally a method of teaching the mother-tongue because Ushinsky realized that children do not yet know their mother-tongue well. Even if they know many words, they often do not fully understand their meaning or, on the other hand, they may be unable to name a number of familiar objects correctly [6].

The success of this method depends on the proper selection of suitable texts and that is why Ushinsky gave painstaking care to their choice as well as to their preparation. Ushinsky explains his concept of the scientific nature of education: We do not say to teachers, "Do this or Do that"; we say "Study the laws of the mental phenomena you wish to control, and proceed in accordance with those laws and the circumstances in which you wish to apply them" [7]. There is an infinite variety of such circumstances, and, what is more, no two pupils are alike. Given this diversity of educational circumstances and pupils, is it possible to issue any general educational prescriptions? It would be difficult to find even one educational measure that did not produce beneficial results in one case, harmful results in another and none at all in a third. This is why we advise teachers to examine as carefully as possible the general physical and spiritual nature of person, to study their own pupils and their environment, to scrutinize the history of various educational measures. They may not always spring to mind, to set themselves a clear, positive educational goal and to pursue it steadfastly, using the knowledge they have acquired and their own good.

Furthermore, Ushinsky was endowed with the special ability to combine a deep analysis of the object of his investigation with a synthetic view, to express analogies of the educational process with other events using inspiring metaphors combined with a refined, flowing literary style. His style is somewhat comparable to that of Comenius who was fond of using numerous comparisons and analogies for the classification of his ideas. Ushinsky was criticized by some narrowly oriented contemporaries, who rejected his approach as unscientific. But, after all, does not education really have a great deal in common with other social and natural processes? Even Ushinsky was too much of a pedagogue to be willing to miss the chance of touching on these common aspects wherever they inspired this lucid observer's meditation.

As a matter of fact, cognition does not proceed solely along the well-trodden paths of formal logic. Art, too, is a way of perceiving reality, and Comenius' and Ushinsky's methods include a number of metaphoric elements suggestive of this form of expression. After all, Ushinsky expressly emphasized that education was a science. The charm of his educational personality lay inter alia in the fact that he was able to combine a strictly scientific approach, based on his wide erudition in many branches of social science, with the creativity of an artist capable of responding to a unique educational situation in a unique manner. Ushinsky correctly anticipated what Makarenko much later imaginatively expressed, that education is the most dialectic of sciences because of the infinite complexity of its subject matter the educational process. It is for this reason that he did not believe in stereotyped educational instructions and directions, but insisted that the teacher should be able like the physician to react in a creative way to every specific situation.

Ushinsky confirmed that the relationships between national education and other nations' education in the following way, "there is no education system that would be common to all nations. Every nation has its own specific education system. Experiences of other nations in the sphere of education are a valuable legacy to all, but not even the best examples can be accepted without being first tried by every nation with the exertion of its own efforts in this sphere" [7]. He also warns that education should not be confused with science and that by itself it cannot solve the questions of life, but can only help to put into effect the history that is, in its turn, formed by the nation. The efficacy of education depends on the degree to which it becomes the subject of public interest.

There are general patterns in the development of humankind. They are repeated by any people. These laws were accurately reproduced by all peoples, regardless of place and time, then there would be no peoples, no nation, no nationalities, no tribes. The historical conditions of peoples' life are very different on the globe and can not fail to determine the differences in the systems of public education of different peoples. All these statements were proved by K.D. Ushinsky.

Nationality should be placed in any nation as the basis of education as its general pattern, as the starting point of any pedagogical idea and the goal of education. K.D. Ushinsky was deeply right, noting the dynamism of the educational ideal of the people, its development associated with the course of the history. The ideal can not be sought only in the past, it includes the present and the aspirations of the people to the future. The people's ideal always expresses the degree of self-consciousness of the people, their conscience, views on the kindness and evil, vice and virtue. This ideal reflects the nature of the people and the changes taking place in society.

The scientist-teacher's research shows, the results of his research are in many respects consonant with the tasks facing the modern system of education. One of such tasks, as already shown above, is the formation of a student's thinking culture, which is carried out in the conditions of developing education. This direction is the most relevant from the standpoint of modern philosophical science, which asserts that education is a process of "awakening the inner forces and capabilities of the student, awakening his soul, cooperative creative activity of the teacher and the student, as a result of which they change both" [2, p. 369].

In view of the foregoing, we should consider the main provisions of the pedagogical concept of K.D. Ushinsky and analyze their importance for modern education, developing under the influence of the processes of globalization and integration.

Obviously, K.D. Ushinsky highlighted an integral pedagogical system aimed at developing the trainee's personality. The so-called anthropological principle of upbringing served as a system-forming factor of this concept. Firstly, oriented education and upbringing were expressed, in the 
setting of learning goals, oriented to the harmonious development of the student's personality. Secondly, the content of education that assumes the development of the personality as an integral system. At the same time, the systematized scientific knowledge that was acquired during the training process was called upon to contribute to the development of the student's own views of the world around him, to the formation of his own worldview and world outlook. This statement corresponds to the understanding of education as a change in the internal image of a person, realized as a result of self-awareness in the world around him. At the same time, a system of own views of the world or world outlook is formed.

According to the scientist's statement, the lack of the ability to correctly express one's thoughts should be considered a serious drawback. In addition, independently acquired knowledge is the source of the formation of independent thoughts [4]. K.D. Ushinsky also stressed that knowledge should not passively accumulate, but should stimulate subsequent more complex mental activity.

Moreover, as the analysis of the conceptual provisions of the philosophical, psychological, and pedagogical science shows, the regularities revealed and described by K.D. Ushinsky were investigated and confirmed in the works of domestic and foreign scientists.

In accordance with the basic principles of the modern philosophy of education, the simple informing or transferring of knowledge should not act as goals, but as a necessary condition for the realization of the basic educational tasks. The latter are achieved through a "stage-by-stage, consistent and continuous practical implementation in the educational process of the most important cognitive functions ... of scientific knowledge" [5, p. 3]. Only in this case, the learning process becomes a process of the person's mental development and the process developing his intellectual-cognitive abilities [5].

It is generally accepted that scientific knowledge is the basis of the content of education. Consequently, this kind of knowledge is called scientific, in which the following cognitive functions are successively realized: descriptive, explanatory and prognostic. The consistent realization of the above functions in real cognitive acts predetermines the formation and development of such intellectual competencies. These are recognition (knowledge), understanding and "the intellectual ability to independently acquire new knowledge based on known assumptions, based on generalizations and descriptions of empirical data, on the basis of knowledge of objective causes, laws, principles, conditions, assumptions, etc." [5, p. 48]. The implementation of these functions in the learning process means that any new knowledge should be explained and proven. In this case, the process of successive formation of various types of thinking is carried out.

Thus, the initial stage of education is marked by the formation of factual thinking, which, being peculiar to all thinking people, attests to the existence of "intellectual competence for recognition or knowledge" [5, p. 55].

At the next stage of training, the critical thinking develops, which is the ability to argue, to prove the causes of known facts, to justify the truth or falsity of some information [5].

During the final stage of education, scientific thinking is formed, which presupposes the ability to independently obtain new knowledge and produce independent logical conclusions. The latter ability, as noted in modern philosophical studies, should consider the highest stage of the development of intelligence, which can be interpreted as the degree of "the ability of a person to express in his language the various volumes of factual and conceptual knowledge ... and use them for their own purposes" [5, p. 51].

The conceptual provisions of the philosophical science on the development of thinking are also confirmed in psychological studies. Thus, S.L. Rubinstein experimentally proved that during the mastery of the knowledge system, the latter "penetrating into the student's consciousness ... transforms the forms of situational thinking and serves as the basis for the development of the forms of rational mental activity that are characteristic of scientific thinking" [3, p. 364]. Moving to a new stage, mental operations are carried out on the basis of a systematized and generalized experience, and not on single situations, which affects the quality of the student's conclusions. In the process of assimilation of theoretical knowledge, the student's thinking "begins to move freely from the individual through the special to the universal, from the casual to the necessary ... and comes to an ever deeper knowledge of reality, to an understanding of the interconnection of its various moments, sides ... its essence" [3, p. 369]. Thus, the student's thinking "develops more and more, as his/her cognitive penetration into reality deepens" [3, p. 369]. Obviously, in the learning process, a transition is made from factual thinking to the development of critical thinking skills and the further development of the scientific thinking foundations.

According to the point of Ushinsky's view, a key role in the development of thinking belongs to the teacher, whose task is to create the prerequisites for the formation of students' thinking. The scientist stressed that the implementation of the new principles of pedagogical science developed by him presupposes the training of future specialists with a different level of professional knowledge and worldview. This idea is also reflected in modern scientific works devoted to the actual problems of education. The findings of these studies show that the main goal of the teacher's job is to help the trainee find his own way in life, thereby promoting his/her self-discovery and self-realization [2].

Thus, from the standpoint of synergetic science, in the process of interpersonal relations, including the relationship between teacher and student, any other action is proposed to be considered as an addition to one's own action. In this case, the relationship between the teacher and the trainee "complement each other, give one another activity, an interest in cooperation" [1, p. 283]. This level of interaction generates a new type of energy. It is called a synergy, which contributes to a significant increase in the effectiveness of training.

In conclusion, the ideas of the system of developmental learning of K.D. Ushinsky are being updated in connection with the issues that arise today in the system of education in connection with the renewal of the content of education, as well as the methods and technologies of instruction. They are carried out under the influence of changes in the political, social and economic spheres of life of modern society. In these conditions, the pedagogical ideas of K.D. Ushinsky concerning the comprehensive development of 
the student's personality, about the peculiarities of the teacher's and student's relationships in the learning process can be claimed by the modern educational establishments in their relationship with the concepts of individualization and personality-oriented learning, competence approach. It should also be emphasized here that Ushinsky was not only a great expert in teaching, but also paid considerable attention to questions of education.

\section{REFERENCES}

1. Громкова М.Т. Синергетические подходы в современном образовании // Синергетическая парадигма. Синергетика образования. - М.: Прогресс-Традиция, 2007. - С. 281-292.

$239 \mathrm{c}$.

5. Федоров Б.И. Курс повышения квалификации учителей «Логико-информационные технологии обучения». ЛИТО. - СПбАППО, 2010. - 279 c.

2. Князева Е.Н. Пробуждающее образование // Синергетические подходы в современном образовании // Синергетическая парадигма. Синергетика образования. - М.: ПрогрессТрадиция, 2007. - С. 369-387.

3. Рубинштейн С.Л. Основы общей психологии. - СПб.: Питер, 2004. $-713 \mathrm{c}$.

4. Ушинский К.Д. Человек как предмет воспитания. Опыт педагогической антропологии. М.: ФАИР-ПРЕСС, 2004. -

6. Model Law on Electronic Commerce of the United Nations Commission on International Trade Law [Электронный pecypc]. - Режим доступа: www.uncitral.org.

7. Paris, UNESCO: International Bureau of Education), vol. 14, no. 1, 1984, and again in vol. 24, no. 3/4, 1994 [Электронный pecypc]. - Режим доступа: www.ibe.unesco.org/sites/default/files/ushinskye.pdf

\section{REFERENCES}

1. Gromkova, M.T. Synergistic approaches in modern education // Synergetic paradigm. Synergetics education. - M.: ProgressTraditsiya, 2007. - P. 281-292.

2. Knyazeva, E.N. Awakening education // Interdisciplinary approaches in modern education // Synergetic paradigm. Synergetics education. - M.: Progress-Traditsiya, 2007. - P. 369387.

3. Rubinstein, S.L. Fundamentals of general psychology. $-\mathrm{SPb}$.: Peter, 2004. $-713 \mathrm{p}$.

4. Ushinsky, K.D. Person as an object of education. Experience of educational anthropology. M.: FAIR-PRESS, 2004. - 239 p.
5. Fyodorov, B.I. Advanced training of teachers «Logical Information Technology Training». LITO. - SPbAPPO, 2010. $279 \mathrm{p}$.

6. Model Law on Electronic Commerce of the United Nations Commission on International Trade Law [Internet Resource]. - Access: www.uncitral.org

7. Paris, UNESCO: International Bureau of Education), vol. 14, no. 1,1984 , and again in vol. 24, no. 3/4, 1994 [Internet Resource]. - Access: www.ibe.unesco.org/sites/default/files/ushinskye.pdf

\section{К. Д. Ушинский о значимости формирования мировоззрения учащихся \\ Е. В. Москалюк}

Аннотация. В статье изложены идеи системы развивающего обучения К.Д. Ушинского, которые актуализуются с ведущими вопросами перед системой обучения, в связи с обновлением содержания образования, а также методов и технологий обучения, которое осуществляется под влиянием изменений в политической, социальной, экономической сферах жизни современного общества. В этих условиях педагогические идеи К.Д. Ушинского о всестороннем развитии личности учащегося, об особенностях взаимоотношений учителя и ученика в процессе обучения, могут быть востребованы современным образованием в их взаимосвязи с концепциями индивидуализации обучения, личностно-ориентированного обучения, компетентностного подхода. Кроме того, было рассмотрено основные положения педагогической концепции К.Д. Ушинского и проанализировано их значимость для современного образования, развивающегося под влиянием процессов глобализации и интеграции.

Ключевые слова: личность, мировоззрение, индивидуализачия обучения, личностно-ориентированное обучение, компетентностный подход. 